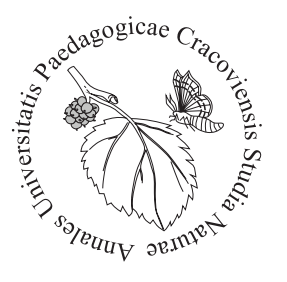

Iwona Konieczna ${ }^{1 \star}$, Grzegorz Rut ${ }^{1}$, Angelika Kliszcz² ${ }^{1}$ Institute of Biology, Pedagogical University of Cracow, Podchorążych 2 St. 30-084 Kraków, Poland, *i.konieczna08@gmail.com ${ }^{2}$ Department of Agrotechnology and Agricultural Ecology, University of Agriculture in Kraków, Mickiewicza St. 21, 31-120 Krakow, Poland

\title{
Photosynthetic activity of Daucus carota L. subsp. sativus (Hoffm.) Schübl. \& G. Martens and Triticum aestivum L. in the presence of copper and vanadium salts
}

\section{Introduction}

Heavy metals are elements that naturally occur in the form of oxides in ores and rocks. They are released through the processing and incineration of various types of waste, transportation vehicles, the mining industry, and metallurgy, including burning energy materials in power plants, cogeneration plants, boiler rooms, and industrial plants (Kabata-Pendias, Pendias, 1999). These include micronutrients, elements necessary for the proper growth and development of organisms (including copper, zinc, chromium, iron) and the trace elements that are dispensable (e.g., cadmium, lead, mercury, vanadium). Although, both types of micronutrients are necessary in many biochemical processes of living organisms, trace elements in excess produce toxic effects disrupting metabolic processes (Kabata-Pendias, Pendias, 1999). Due to the ability of intensive migration and accumulation, heavy metals are a factor causing toxic contamination of soils, water, and air (Karczewska et al., 2008). The toxicity of heavy metals depends on the degree of their concentration and the path of penetration into the environment, the chemical form in which they occur, the type of their interaction with other metals, and the species and age of the organisms (Maciejewska, 2003).

Copper $(\mathrm{Cu})$ is an element strongly bound in surface layers of soil and does not move into its profile. In moderate climate, it remains in soils between 1 and 3 thousand years (Bowen, 1979). This element occurs in all types of waters. Its content is very different and depends on the surrounding geological formation and impurities (Formicki, 2010). Due to the strong sorption of other substances, copper usually accumulates in bottom sediments. Sometimes, it is transported with water in the form of a colloidal suspension of various salts or minerals (Kabata-Pendias, Pendias, 1979; 1999). 
Most often, such situations occur in mining and metallurgical areas, where the permissible content of this metal can be exceeded several thousand times. Besides the industrial emissions, the sources of copper in the soil are mineral and organic fertilizers, plant protection chemicals, and municipal waste. Tolerance of plants to excess copper is relatively high, and they can grow in environments contaminated with this element (Kabata-Pendias, Pendias, 1999). Plants are relatively resistant to copper, but its excess causes disturbances in metabolism and, as a consequence, the copper contamination limits growth and development. Excess copper mainly damages the DNA of cells, manifesting in changes in the permeability of cell membranes by increasing the secretion of some cations and anions (e.g., $\mathrm{K}^{+}, \mathrm{PO}_{4}{ }^{3-}$ ). It also causes disturbances in electron flow in the process of photosynthesis (Maksymiec, 1997).

The other toxic element found in the environment is vanadium (V). The biological role of vanadium is involved in the metabolism of lipids, phosphotransferases, sugars, and monoamine oxidases. It is also involved in the sodium-potassium and calcium-magnesium systems. Vanadium is needed mainly in the metabolism of algae cells in which it stimulates photosynthesis. Additionally, it is engaged in the reduction of hydrogen peroxide through the vanadium-bromoperoxidase enzyme, thus acting as an electron transporter $\left(\mathrm{V}^{3+}-\mathrm{V}^{4+}-\mathrm{V}^{5+}\right)$. For higher plants, vanadium is not necessary for proper functioning. However, in small concentrations, it positively influences the synthesis of chlorophyll. It also works catalytically in the process of nitrogen fixation by bacteria of the genus Rhizobium and free-living bacteria. In plants, only the biological reduction of vanadium from the $\mathrm{VO}_{3}{ }_{3}^{-}$form to the $\mathrm{VO}_{2}{ }^{+}$form is protective, and the vanadium is harmful at a higher degree of oxidation (Morell et al., 1986).

The aim of this study was to determine the effect of copper and vanadium salts with different molar concentrations on the photosynthetic activity of carrots (Daucus carota L. subsp. sativus (Hoffm.) Schübl. \& G. Martens) and winter wheat (Triticum aestivum $\mathrm{L}$.). The assessment of the chlorophyll content and chlorophyll fluorescence kinetics parameter in young specimens were measured.

\section{Material and methods}

Carrot seeds and wheat grains were put on sterilised Petri dishes wetted with distilled water, and stored in the dark, at room temperature. After 9 days, similar morphologically seedlings in pots with sand were planted and cultivated for 5 weeks. In the first week, sand cultures with seedlings were watered regularly with both distilled water (10 $\mathrm{ml}$ each) and Steiner's medium (10 $\mathrm{ml}$ each). In the next four weeks, the plants were treated once a week with copper $\left(\mathrm{CuSO}_{4}\right.$, copper (II) sulphate) and vanadium salts $\left(\mathrm{H}_{4} \mathrm{NO}_{3} \mathrm{~V}\right.$, azanium; oxido(dioxo)vanadium, according to IUPAC) with both mentioned salts at concentrations of $0.6 \mathrm{mM}$ and $3 \mathrm{mM}(10 \mathrm{ml}$ each $)$ and with Steiner's 

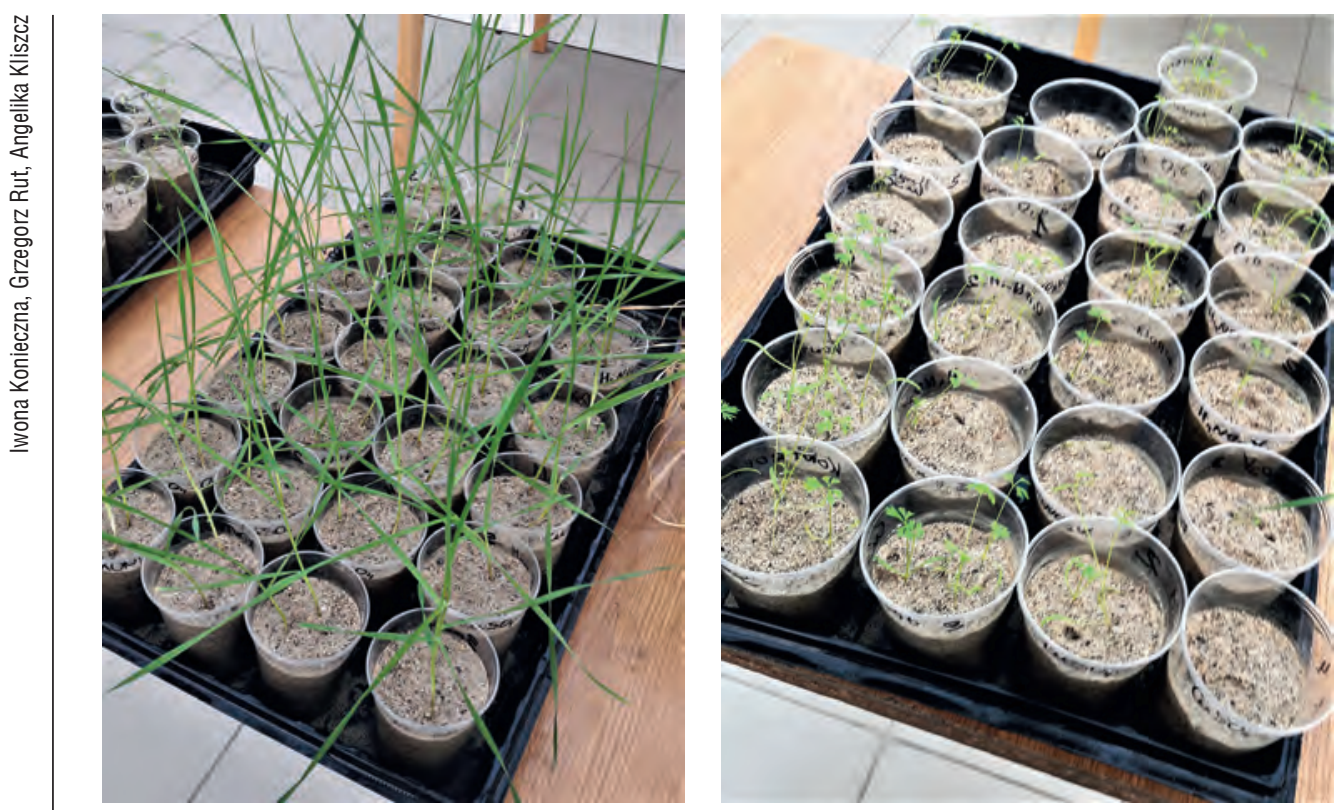

Fig. 1. Sand cultures of cultivated carrot (Daucus carota L. subsp. sativus (Hoffm.) Schübl. \& G. Martens) and wheat (Triticum aestivum L.) treated with copper and vanadium salts (Photo. I. Konieczna)

medium (10 ml each). The control was only watered with both distilled water $(10 \mathrm{ml}$ each) and Steiner's medium (10 ml each) (Fig. 1).

The determination of chlorophyll content and measurement of chlorophyll $a$ fluorescence After five weeks of carrot and wheat cultivation, the total chlorophyll (Chl) content was measured using a SPAD chlorophyll meter (Geomor-Technik) at room temperature according to the procedure provided by the manufacturer. At room temperature, chlorophyll $a$ fluorescence measurements using a FMS-1 fluorometer (Fluorescence Monitoring System) of Hansatech Instruments England were made, according to the method used by Strasser et al. (2000). In order to quench the phase of bright photosynthesis, carrot and wheat leaves were adapted to the darkness for 20 minutes using clips. After that time, by treating the plants with a light intensity of $1500 \mu \mathrm{mol} \mathrm{m}^{-2} \mathrm{~s}^{-1}$ for $1 \mathrm{~s}$, measurements of the parameters $\mathrm{F}_{0}$ (zero fluorescence), $\mathrm{F}_{\mathrm{m}}$ (maximum fluorescence), $F_{v}=\left(F_{m}-F_{0}\right)$ (variable fluorescence), and $F_{v} / F_{m}$ (maximum photochemical efficiency PSII) were measured (Kalaji, Łoboda, 2010).

Statistical analysis The results were analysed using ANOVA/MANOVA parametric statistical tests, single and multifactor, based on the Duncan test, with $\mathrm{p} \leq 0.05$. Average values from $10 \mathrm{in}$ - 
dependent repetitions were tested, along with the standard deviation $( \pm S D)$. The calculations were made using StatSoft, Inc. (2017) - STATISTICA (data analysis software system), version 13. www.statsoft.com.

\section{Results and discussion}

Heavy metals accumulated in the soil disturb the basic physiological functions of microorganisms. They lead to an imbalance in the processes of the decomposition and metabolism of organic matter, inhibit the growth and development of plants, and reduce their resistance to pathogens (Becker et al., 2006; Yanai et al., 2006). Plants collect heavy metals from the soil through the root system and the air through leaf blades. The most easily collected metals are from the soil in the form of free ions, and metals in the form of complexes, which are activated by substances secreted from the roots of plants (Inal et al., 2007). The amount of heavy metals taken in by plants depends on the type of metal, the form of its occurrence, its content in the soil, and the species of the plant that assimilates it (Jin et al., 2005). The excessive accumulation of heavy metals in plants adversely affects their physiological and biochemical processes (Możdżeń et al., 2016; 2017). Heavy metals alter photosynthesis, respiration, and mineral uptake. They contribute to the degradation of cell organelles and, in extreme cases, lead to the death of the entity (Jing et al., 2007).

The cause of any changes in the metabolic activity of plants can be an uncontrolled increase in harmful substances that cause cell-toxic oxidative stress (Bartosz, 2003). In the presence of heavy metals, various life activities of organisms are inhibited, including protein activity through the formation of covalent bonds (McGrath et al., 2001), the reduction of the stomatal conductance by increasing the synthesis of abscisic acid (Parys et al., 1998), water decomposition reactions caused by damage to the oxygen-releasing complex (Gonzalez-Mendoza et al., 2007), lipid synthesis in thylakoids and protein antenna system (Joshi, Mohanty, 2004), dark reactions (Burzyński, Żurek, 2007), and the reduction of PSII activity caused by slowing down the reduction and oxidation of plastochinone molecules (Strasser et al., 1995).

The photosynthetic response of plants to stress is partly the result of changes in the chlorophyll fluorescence reaction; whereas, the chlorophyll fluorescence efficiency is related to the chlorophyll content (Kalaji, Łoboda, 2010). Chlorophyll $a$, is an important indicator of photosynthesis that converts solar energy absorbed by other molecules of chlorophyll into energy, which is used by plants in biological processes. Therefore, the chlorophyll content inevitably affects the fluorescence, ultimately affecting plant photosynthesis. The key organelles of chlorophyll synthesis are chloroplasts. They participate in the process of photosynthesis, in the assimilation of nitrogen and sulphur, and also in the metabolism of proteins and nucleic acids. The presence of heavy metals 
in chloroplasts contributes to their ultrastructural changes, including the increase in the number and size of plastoglobules, the disorganization of grana and thylakoids (Solymosi, Bertrand, 2012), the disturbance of electron transport in the process of photosynthesis, and the induction of chlorosis (Lewis et al., 2001; Yruela, 2005).

In this experiment, the negative effect of copper and vanadium salts on the chlorophyll content and the photosystem II (PSII) activity in carrot and wheat plants were observed (Fig. 2). Measurements of the total chlorophyll (Chl) content in D. carota showed clear changes in the pigment content at the highest copper salt concentration $\left(3 \mathrm{mM} \mathrm{CuSO}_{4}\right)$ and in each of the vanadium solutions, in relation to the control plants (Fig. 2A). The Chl content in T. aestivum generally was decreased in plants treated with $3 \mathrm{mM} \mathrm{H}_{4} \mathrm{NO}_{3} \mathrm{~V}$ (Fig. 2B). Similarly, chlorophyll reduction has been reported, e.g., in the leaves of common bean (Phaseolus vulgaris L.), tomato (Solanum lycopersicon L.), radish (Raphanus sativus L.), and broad bean (Vicia faba L.) (Perez-Espinosa et al., 2002; Gad, 2005; Kandil, 2007; Yavakumar et al., 2007). Limitation of Chl production is connected with direct inhibition by heavy metals of enzymes involved in chlorophyll $a$ and $b$ synthesis, which play an important role in chloroplast membrane formation and participate in photosynthesis, and thus affect chlorophyll fluorescence (Gruca-Królikowska, Wacławek, 2006).

Tab. 1. The chlorophyll a fluorescence parameters of carrot (Daucus carota L. subsp. sativus (Hoffm.) Schübl. \& G. Martens) - A and wheat (Triticum aestivum L.) - B plants watered in the growth phase with copper $\left(\mathrm{CuSO}_{4}\right)$ and vanadium $\left(\mathrm{H}_{4} \mathrm{NO}_{3} \mathrm{~V}\right)$ salt solutions, at various concentrations $(0.6 \mathrm{mM}$ and $3 \mathrm{mM})$

\begin{tabular}{|c|c|c|c|c|c|c|c|c|c|c|}
\hline \multirow{4}{*}{ 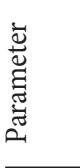 } & & & \multicolumn{8}{|c|}{ Concentration of the solution $[\mathrm{mM}]$} \\
\hline & \multirow{2}{*}{\multicolumn{2}{|c|}{ Control }} & \multirow{2}{*}{\multicolumn{2}{|c|}{$\begin{array}{c}\mathrm{CuSO}_{4} \\
0.6\end{array}$}} & \multicolumn{6}{|c|}{$\mathrm{H}_{4} \mathrm{NO}_{3} \mathrm{~V}$} \\
\hline & & & & & \multicolumn{2}{|c|}{3} & \multicolumn{2}{|c|}{0.6} & \multicolumn{2}{|c|}{3} \\
\hline & A & $\mathrm{B}$ & A & $\mathrm{B}$ & A & B & A & B & A & B \\
\hline $\mathrm{F}_{0}$ & 249.6 & 200.2 & 228.6 & 225.3 & 160.8 & 224.0 & 210.6 & 206.0 & 121.1 & 228.3 \\
\hline $\mathrm{F}_{\mathrm{m}}$ & 1541.6 & 1251.8 & 1514.4 & 1490.3 & $104.9^{*}$ & 1496.3 & 1308.1 & 1342.3 & $751.3^{\star}$ & 1412.0 \\
\hline $\mathrm{F}_{\mathrm{v}}$ & 1292.0 & 1068.5 & 1285.8 & 1265.0 & $88.1^{*}$ & 1272.3 & 1097.3 & 1136.3 & $630.9^{*}$ & 1183.8 \\
\hline$\underline{\mathrm{F}_{\mathrm{v}} / \mathrm{F}_{\mathrm{m}}}$ & 0.84 & 0.85 & 0.85 & 0.85 & $0.08^{*}$ & 0.85 & 0.75 & 0.85 & $0.42^{\star}$ & 0.84 \\
\hline
\end{tabular}

$\mathrm{F}_{0}$ - zero fluorescence, $\mathrm{F}_{\mathrm{m}}-$ maximum fluorescence, $\mathrm{F}_{\mathrm{v}}=\left(\mathrm{F}_{\mathrm{m}}-\mathrm{F}_{0}\right)$ - variable fluorescence, $\mathrm{F}_{\mathrm{v}} / \mathrm{F}_{\mathrm{m}}-$ maximum photochemical efficiency PSII; mean values $(\mathrm{n}=10)$ marked with an asterisk $\left({ }^{*}\right)$ differ significantly according to Duncan test at $\mathrm{p} \leq 0.05$

The kinetics of chlorophyll $a$ fluorescence illustrates both short-term and longterm effects of heavy metal ions on photosynthesis, and it is expressed using chlorophyll fluorescence parameters (Kalaji, Łoboda, 2010). The parameters of chlorophyll a fluorescence allow non-invasive determination of the efficiency of primary photosynthesis reactions (Krupa, Baszyński, 1995). In experiments, a statistically significant effect was indicated with $3 \mathrm{mM}$ solutions of copper ions $\left(\mathrm{CuSO}_{4}\right)$ and vanadium $\left(\mathrm{H}_{4} \mathrm{NO}_{3} \mathrm{~V}\right)$ on photosynthetic activity of young plants, expressed as measurements of 

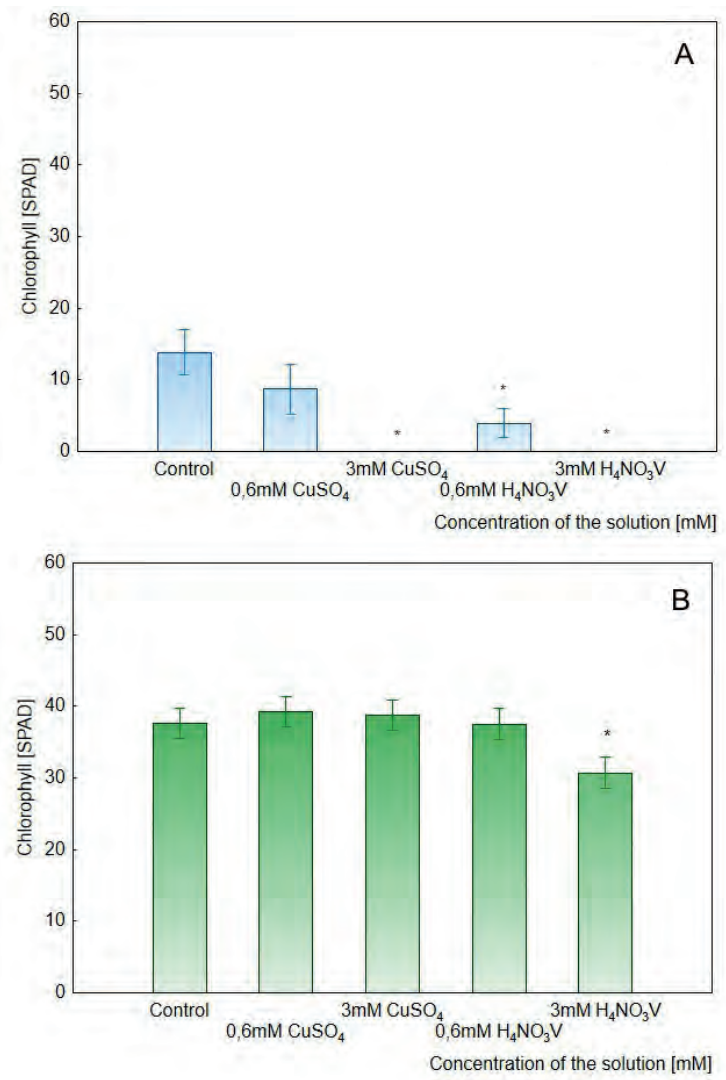

Fig. 2. The chlorophyll content in carrot (Daucus carota L. subsp. sativus (Hoffm.) Schübl. \& G. Martens) - (A) and wheat (Triticum aestivum L.) - (B) leaves, grown with copper $\left(\mathrm{CuSO}_{4}\right)$ and vanadium $\left(\mathrm{H}_{4} \mathrm{NO}_{3} \mathrm{~V}\right)$ salts solutions, at various concentrations $(0.6 \mathrm{mM}$ and $3 \mathrm{mM})$; mean values $(\mathrm{n}=10)$ marked with an asterisk $\left(^{*}\right)$ differ significantly according to Duncan test at $\mathrm{p} \leq 0.05$

kinetics of chlorophyll $a$ fluorescence. For wheat plants, the copper and vanadium salts did not cause significant changes in the chlorophyll $a$ fluorescence (Tab. 1).

The increase in the value of zero fluorescence $\left(\mathrm{F}_{0}\right)$ was most probably caused by the limitation of the ability to transmit excitation energy in antenna complexes PSII or reducing the energy absorption efficiency to PSII as a result of protein dissociation (Murkowski, 2002). Changes in the maximum fluorescence index $\left(\mathrm{F}_{\mathrm{m}}\right)$ indicated a reduced ability to reduce electron acceptors in PSII. The reduction in variable fluorescence efficiency $\left(\mathrm{F}_{\mathrm{v}}\right)$ by thylakoid damage was caused, in which a large part of the excitation energy dissipated in the form of heat, and consequently decreased the activity PSII. The maximum photochemical efficiency $\left(\mathrm{F}_{\mathrm{v}} / \mathrm{F}_{\mathrm{m}}\right)$ for healthy plants under control conditions in the full development phase is assumed to be 0.83 (Björkmann, Demming, 1987). Lowering the value of this parameter indicates the reduced efficiency of electron transport, the degradation of proteins, and the inactivation of PSII reaction 
centres. This parameter is considered a basic indicator of photosynthesis (Kalaji, Łoboda, 2010; Puła et al., 2019).

The main method of tolerating or neutralising the toxicity of metals is the biosynthesis by organisms of various cellular biomolecules. This includes the induction of proteins, organic acids, glutathione, phytochelatins, or cellular secretions, including flavonoids and phenolic compounds, specific amino acids (proline and histidine) and hormones (salicylic acid, jasmonic acid and ethylene). When the above-mentioned strategies are not able to stop heavy metal poisoning, the balance of cellular systems in plants is disturbed and leads to the increased induction of reactive oxygen species (ROS). In order to alleviate the harmful effects of free radicals, plant cells have developed an antioxidant defence mechanism, which consists of the activation of enzymatic antioxidants acting as "scavengers" of free radicals. These include superoxide dismutase (SOD), catalase (CAT), ascorbic peroxidase (APX), glutathione peroxidase (GPX) and glutathione reductase (GR), and non-enzymatic antioxidants, such as ascorbate (AsA), glutathione (GSH), carotenoids, alkaloids, tocopherols, proline, and phenolic compounds (flavonoids, tannins and lignin) (Emamverdian et al., 2015).

Although plants constantly create new defence strategies against stress, and some of the biological molecules involved in metal detoxification have antiradical, chelating and antioxidant effects, heavy metals still cause a disturbance of the metabolic balance of plants. Exploitation and regulation of defence mechanisms depend on many factors, including on the plant species, the stage of growth, and the type of heavy metal (Ociepa-Kubicka, Ociepa, 2012; Emamverdian et al., 2015).

Conclusion

In this experiment, the copper and vanadium salts effect on photosynthetic activity of carrot and wheat plants depend on salts concentrations. Significant effects of $3 \mathrm{mM}$ solutions of copper ions and vanadium on photosynthetic activity of carrot plants were observed. For wheat plants, the copper and vanadium salts did not cause significant changes in the chlorophyll $a$ fluorescence. Chlorophyll content decreased with increasing of salt concentrations.

References

Becker, J.M., Parkin, T., Nakatsu C.H., Wilbur, J.D., Konopka, A. (2006). Bacterial activity, community structure and centimeter-scale spatial heterogeneity in contaminated soil. Microbial Ecology, 51, 221-231. DOI: 10.1007/s00248-005-0002-9

Björkmann, O., Demming, B. (1987). Photon yield of $\mathrm{O}_{2}$ evolution and chlorophyll fluorescence characteristics at $77 \mathrm{~K}$ among vascular plants of diverse origins. Planta, 170, 489-504. DOI: 10.1007/ BF00402983 
Bowen, H.J.M. (1979). Environmental chemistry of the elements. London: Academic Press.

Burzyński, M., Żurek, A. (2007). Effects of copper and cadmium on photosynthesis in cucumber cotyledons. Photosynthetica, 45, 239-244. DOI: 10.1007/s11099-007-0038-9

Emamverdian, A. Ding, Y., Mokhberdoran, F., Xie, Y. (2015). Heavy metal stress and some mechanisms of plant defense response. The Scientific World Journal, 1-18. DOI: 10.1155/2015/756120

Formicki, G. (2010). Metale ciężkie w środowisku wodnym. Właściwości toksyczne, biologiczne dostępność $i$ kumulacja w tkankach zwierząt. Kraków: Wydawnictwo Naukowe Uniwersytetu Pedagogicznego. [In Polish]

Gad, N. (2005). Interactive effect of salinity and cobalt on tomato plants. II. Some physiological parameters as affected by cobalt and salinity. Research Journal of Agriculture and Biological Science, 1(3), 270-276.

Gonzalez-Mendoza, D., Espadas y Gilb, F., Santamaria, J.M., Zapata-Pereza, O. (2007). Multiple effects of cadmium on the photosynthetic apparatus of Avicennia germinans L. as probed by OJIP chlorophyll fluorescence measurement. Zeitschrift für Naturforschung, 62c, 265-272. DOI: 10.1515/znc-2007-3-418

Gruca-Królikowska, S., Wacławek W. (2006). Metale w środowisku. Cz. II. Wpływ metali ciężkich na rośliny. Chemia, Dydaktyka, Ekologia, Metrologia, 11(1-2), 41-55. [In Polish]

Inal, A., Gunes, A., Zhang, F., Cakmak, I. (2007). Peanut/maize intercropping induced changes in rhizosphere and nutrient concentrations in shoots. Plant Physiology and Biochemistry, 45, 350-356. DOI: 10.1016/j.plaphy.2007.03.016

IUPAC nomenclature https://pubchem.ncbi.nlm.nih.gov

Jin, C.W., Zheng, S.J., He, Y.F., Zhou, G.D., Zhou, Z.X. (2005). Lead contamination in tea garden soils and factors affecting its bioavailability. Chemosphere, 59, 1151-1159. DOI: 10.1016/j. chemosphere.2004.11.058

Jing, Y., He, Z., Yang, X. (2007). Role of soil Rhizobacteria in phytoremediation of heavy metal contaminated soils. Journal of Zhejiang University Science B, 8(3), 192-207. DOI: 10.1631/jzus.2007.B0192

Joshi, A., Kothari, S.L. (2007). High copper levels in the medium improves shoot bud differentiation and elongation from the cultured cotyledons of Capsicum annuum L. Plant Cell Tissue and Organic Culture, $88,127-133$. DOI: $10.1007 / \mathrm{s} 11240-006-9171-6$

Joshi, M.K., Mohanty, P. (2004). Chlorophyll $a$ fluorescence as a probe of heavy metal ion toxicity in plants. In: G.C. Papageorgiou (ed.). Advances in photosynthesis and respiration, 19, 637-661. DOI: 10.1007/978-1-4020-3218-9_25

Kabata-Pendias, A., Pendias, H. (1979). Pierwiastki śladowe w środowisku biologicznym. Warszawa: Wydawnictwo Geologiczne. [In Polish]

Kabata-Pendias, A., Pendias, H. (1999). Biogeochemia pierwiastków śladowych. Warszawa: Wydawnictwo Naukowe PWN. [In Polish]

Kalaji, M.H., Łoboda, T. (2010). Fluorescencja chlorofilu w badaniach stanu fizjologicznego roślin. Warszawa: Wydawnictwo Szkoły Głównej Gospodarstwa Wiejskiego. [In Polish]

Kandil, H. (2007). Effect of cobalt fertilizer on growth, yield and nutrient status of faba bean (Vicia faba L.) plants. Journal of Applied Sciences Research, 3(9), 867-872.

Karczewska, A., Spiak, Z., Kabała, C., Gałka, B., Szopka, K., Jezierski, P., Kocan, K. (2008). Ocena możliwości zastosowania wspomaganej fitoekstrakcji do rekultywacji gleb zanieczyszczonych emisjami hutnictwa miedzi. Wrocław: Wydawnictwo Zante. [In Polish]

Krupa, Z., Baszyński, T. (1995). Some aspects of heavy metals toxicity towards photosynthetic apparatus-direct and indirect effects on light and dark reaction. Acta Physiologiae Plantarum, 17, 177-190.

Lewis, S., Donkin, M.E., Depledge, M.H. (2001). Hsp70 expression in Enteromorpha intestinalis (Chlo- 
rophyta) exposed to environmental stressors. Aquatic Toxicology, 51, 277-291. DOI: 10.1016/S0166445X(00)00119-3

Maciejewska, A. (2003). Problematyka rekultywacji gleb zanieczyszczonych metalami ciężkimi w świetle literatury. Obieg pierwiastków w przyrodzie, 539-550. [In Polish]

Maksymiec, W. (1997). Effect of copper on cellular processes in higher plants. Photosynthetica, 34, 321342. DOI: $10.1023 / \mathrm{A}: 1006818815528$

McGrath, S., Lombi, E., Zhao, F.-J. (2001). What's new about cadmium hyperaccumulation? New Phytology, 149, 2-3. DOI: 10.1046/j.1469-8137.2001.00024.x

Morell, B.C., Lepp, N.W., Phipps, D.A. (1986). Vanadium uptake by higher plants: some recent developments. Environmental Geochemistry and Health, 8, 14-18. DOI: $10.1007 /$ BF02280116

Możdżeń, K., Rzepka, A. (2016). Rola łupiny nasiennej podczas kiełkowania i wzrostu nasion bobu (Vicia faba L.) w obecności siarczanu ołowiu. Annales UMCS Sectio E Agricultura, 71(4), 55-65. [In Polish]

Możdżeń, K., Wanic, T., Rut, G., Łaciak, T., Rzepka, A. (2017). Toxic effect on the physiological processes in Pinus sylvestris L. grown under high copper content. Photosynthetica, 55(1), 193-200. DOI: 10.1007/s11099-016-0229-3

Murkowski, A. (2002). Oddziaływanie czynników stresowych na luminescencję chlorofilu w aparacie fotosyntetycznym roślin uprawnych. Monografia 61, Lublin: Instytut Agrofizyki im. Bohdana Dobrzańskiego PAN. [In Polish]

Ociepa-Kubicka, A., Ociepa, E. (2012). Toksyczne oddziaływanie metali ciężkich na rośliny, zwierzęta i ludzi. Inżynieria i Ochrona Środowiska, 15(2), 169-180. [In Polish]

Parys, E., Romanowska, E., Siedlecka, M., Poskuta, J. (1998). The effects of lead on photosynthesis and respiration in detached leaves and in mesophyll protoplasts of Pisum sativum. Acta Physiologiae Plantarum, 20, 313-322. DOI: 10.1007/s11738-998-0064-7

Perez-Espinosa, A., Moreno-Caselles, J., Moral, R., Perez-Murcia, M.D., Gomez, I. (2002). Effect of cobalt on chlorophyll and carotenoids contents in tomato plants. Journal of Plant Nutrition, 25(9), 19331940. DOI: $10.1081 /$ PLN-120013285

Puła, J., Barabasz-Krasny, B., Lepiarczyk, A., Zandi, P., Możdżeń, K. (2019). Activity of the photosynthetic apparatus in Phaseolus vulgaris under the Cd stress. Notulae Botanicae Horti Agrobotanici Cluj-Napoca, 47(2), 405-411. DOI: $10.15835 /$ nbha47111328

Solymosi, K., Bertrand, M. (2012). Soil metals, chloroplasts, and secure crop production: a review. Agronomy for Sustainable Development, 32, 245-272. DOI: 10.1007/s13593-011-0019-z

Strasser, R.J., Srivastava, A., Govindjee (1995). Polyphasic chlorophyll $a$ fluorescence transient in plants and cyanobacteria. Photochemistry and Photobiology, 61, 32-42.

Strasser, R.J., Srivastava, A., Tsimilli-Michael, M. (2000). The fluorescence transient as a tool to characterize and screen photosynthetic samples, probing photosynthesis: mechanism, regulation and adaptation. In: M. Yunus, U. Pathre, P. Mohanty (eds.), Probing photosynthesis. London: Taylor and Francis, 443-480.

Yanai, J., Fang-Jie, Z., McGrath, S.P., Kosaki, T. (2006). Effect of soil characteristics on Cd uptake by the hyperaccumulator Thlaspi caerulescens. Environmental Pollution, 139, 167-174. DOI: 10.1016/j. envpol.2005.03.013

Yavakumar, K., Jaleel, Ch.A., Vijarengan, P. (2007). Changes growth, biochemical constituents, and antioxidant potentials in radish (Raphanus sativus L.) under cobalt stress. Turkish Journal of Biology, $31,127-136$.

Yruela, I. (2005). Copper in plants. Brazilian Journal of Plant Physiology, 17, 145-156. DOI: 10.1590/ S1677-04202005000100012 


\begin{abstract}
The aim of this study was to investigate the influence of copper and vanadium ions on the photosynthetic activity of carrot (Daucus carota L. subsp. sativus (Hoffm.) Schübl. \& G. Martens) and winter wheat (Triticum aestivum $\mathrm{L}$.). Measurements of the total chlorophyll content were performed using a SPAD chlorophyll meter, and the basic chlorophyll $a$ fluorescence parameters were determined using a FMS-1 fluorometer Hansatech. Aqueous solutions of copper $\left(\mathrm{CuSO}_{4}\right)$ and vanadium $\left(\mathrm{H}_{4} \mathrm{NO}_{3} \mathrm{~V}\right)$ salt with molar concentrations of $0.6 \mathrm{mM}$ and $3 \mathrm{mM}$ were used. The control group consisted of plants watered with distilled water. With an increase in the concentration of heavy metal ions, a decrease in the content of chlorophyll both in carrots and in wheat was observed, and significant changes in the activity of the photosystem II were demonstrated. Statistically significant effects of $3 \mathrm{mM}$ solutions of copper and vanadium ions on photosynthetic activity were only shown in D. carota L. subsp. sativus. In T. aestivum L., none of the heavy metal ions induced significant changes in the values of chlorophyll $a$ fluorescence.
\end{abstract}

Key words: photosynthesis, carrot, wheat, heavy metals, copper sulphate, ammonium metavanadate

Received: [2018.04.09]

Accepted: [2018.11.05]

\title{
Aktywność fotosyntetyczna Daucus carota L. subsp. sativus (Hoffm.) Schübl. \& G. Martens i Triticum aestivum L. w obecności jonów miedzi oraz wanadu
}

Streszczenie

Celem niniejszej pracy było zbadanie wpływu jonów miedzi i wanadu na aktywność fotosyntetyczną marchwi uprawnej (Daucus carota L. subsp. sativus (Hoffm.) Schübl. \& G. Martens) i pszenicy ozimej (Triticum aestivum L.). Przeprowadzono pomiary całkowitej zawartości chlorofilu - chlorofilomierzem SPAD oraz wyznaczono podstawowe parametry fluorescencji chlorofilu a przy użyciu fluorymetru FMS-1 - Hansatech. W badaniach wykorzystano wodne roztwory soli miedzi $\left(\mathrm{CuSO}_{4}\right)$ i wanadu $\left(\mathrm{H}_{4} \mathrm{NO}_{3} \mathrm{~V}\right)$, o stężeniach molowych $0,6 \mathrm{mM}$, i $3 \mathrm{mM}$. Grupę kontrolną stanowiły rośliny podlewane wodą destylowaną. Zarówno u marchwi, jak i u pszenicy, wraz ze wzrostem koncentracji jonów metali ciężkich, zaobserwowano zmniejszenie zawartości chlorofilu oraz wykazano istotne zmiany w aktywności fotosystemu II. Pomiary kinetyki fluorescencji chlorofilu $a$ jedynie u roślin $D$. carota wykazały istotny statystycznie wpływ $3 \mathrm{mM}$ roztworów jonów miedzi i wanadu na aktywność fotosyntetyczną badanych roślin. U T. aestivum L. żaden z jonów metali ciężkich nie wywoływał znaczących zmian w wartościach parametrów fluorescencji chlorofilu $a$.

Key words: fotosynteza, marchew, pszenica, metale ciężkie, siarczan miedzi (II), metawanadan amonu

Information about authors

Iwona Konieczna https://orcid.org/0000-0002-9538-8516

She is a student of biology. She is interested in allelopathic interaction between plants and effect of heavy metals on plant morphology and physiology.

Grzegorz Rut https://orcid.org/0000-0001-6719-3060

His research topic concern the course of basic physiological processes in plants (photosynthesis, respiration, chlorophyll fluorescence, transpiration), concentration chlorophyll, antocyanins, and reactions of plants, mainly mosses (Polytrichum piliferum, Mnium undulatum), ferns (Platycerium bifurcatum), and vascular plants (Oxalis acetosella, O. corniculata) on abiotic stress factors (excess and deficiency of solar radiation, hypoxia, anoxia, excess heavy metals, herbicides, salinity, changes in carbon dioxide concentration, drought stress, and low temperature).

\section{Angelika Kliszcz}

She is focusing on enhancing the understanding of the influence of different factors on soil structure and fertility. Particularly, she is investigating the interaction of plants with the physical, chemical, and biological properties of the soil. She is also interested in organic methods of plant production and soil-enriching substances. 